All letters must be typed with double spacing and signed by all authors.

No letter should be more than 400 words.

For letters on scientific subjects we normally reserve our correspondence columns for those relating to issues discussed recently (within six weeks) in the BMF.

We do not routinely acknowledge letters. Please send a stamped addressed envelope if you would like an acknowledgment.

Because we receive many more letters than we can publish we may shorten those we do print, particularly when we receive several on the same subject.

\section{Preventing osteoporosis}

SIR,-Dr M R Law and colleagues' review of strategies for preventing osteoporosis and hip fracture contains several controversial conclusions, not the least of which is the statement that "hormone replacement therapy is likely to have an appreciable impact on the public health issue of hip fracture only if it is continued indefinitely after the menopause." Though the optimum duration of such therapy has not been established, there is little evidence to support this conclusion.

In favour of their statement the authors quote several studies, ${ }^{2.5}$ mainly observational, in which the risk of hip fracture was reduced most in current users of hormone replacement therapy (as opposed to past users). Table VI of their paper gives data on the time since last taking oestrogen in these studies but does not include any information about the duration of oestrogen use, which several studies have shown to be positively related to the reduction in risk of hip fracture..$^{236}$ Without information about the duration of use in current versus past users the significance of the respective reductions in the risk of fracture cannot be assessed. Moreover, the apparent protection conferred by only brief exposure in some studies may have resulted from errors of classification.

The authors also quote the paper of Christiansen et $a l^{b}$ to support their argument that protection is lost soon after women stop hormone replacement therapy. In fact, Christiansen et al concluded that "even temporary hormone replacement therapy after the menopause will have a lasting beneficial effect on bone mass," an interpretation strongly supported by the data shown in figure 1 of their paper. Moreover, as Christiansen et al point out, Lindsay et al's study was of women after oophorectomy ${ }^{9}$ and the results may have been biased by the comparison of bone loss during the first four years after the withdrawal of hormone in one group with bone loss during the first eight years in untreated women after oophorectomy; when bone loss in untreated women during the first four years was used for comparison the rates in the two groups were similar.

Though some of the protective effects of hormone replacement therapy may be sustained only in current users (for example, possible effects on muscle strength and mobility), most current evidence supports the contention that a limited period of hormone replacement therapy, numbered in years, confers a lasting beneficial effect on bone mass and thus probably also on the risk of fracture. As the authors state, lifelong treatment would be a departure from current practice in the United Kingdom, and the certain prospect of poor compliance together with the possibility of an increased risk of serious side effects would greatly reduce its acceptability. Nobody would argue against the need for more accurate guidelines on the duration of treatment, but until such information becomes available it would be both unfortunate and inappropriate if the arguments put forward by Dr Law and colleagues discouraged long term but finite prescriptions of hormone replacement therapy to prevent and treat osteoporosis

Department of Medicine.

J E COMPSTON

University of Cambridge Clinical School.

Addenbrooke's Hospital

Cambridge CB2 2QQ

1 Law MR, Wald NK, Meade TW. Strategies for prevention of osteoporosis and hip fracture. BMF 1991;303:453-9. (24 August.)

Weiss NS, Ure CL, Ballard JH, Williams AR, Daling JR Decreased risk of fractures of the hip and lower forearm with postmenopausal use of estrogen. $N$ Engl f Med 1980;303 $1195-8$.

3 Paganini-Hill A, Ross RK, Gerkins VR, Henderson BE, Arthu M, Mack TM. Menopausal estrogen therapy and hip fractures. Ann Intern Med 1981:95:28-31.

4 Kiel DP, Felson DT, Anderson JJ, Wilson PWF, Moskowitz MA. Hip fracture and he use of esrogens in postmenopausa MA. Hip fracture and the use of estrogen

5 Panen. N Engl f Med 1987,317.169-74. gani-Hill A, Chao A, Ross RK, Hendeson BE. Exercise an other factors in the prevention of hip fracture: the leisure world studs. Epidemiology 1991; ;i: 16-25.

6 Johnson RE, Specht EE. The risk of hip fracture in postmenopausal females with and without estrogen drug exposure. Am J Public Health 1981;71:138-44.

7 Kreiger N, Kelsey JL, Holford TR, O'Connor T. An epidemiologic study of hip fracture in postmenopausal women. Am f Epidemiol 1982;116:141-8.

8 Christiansen C, Christensen MS, Transbol I. Bone mass in postmenopausal women after withdrawal of oestrogen/gestagen replacement therapy. Lancet 1981;i:459-61

9 Lindsay R, Hart DM, MacLean A, Clark AC, Kraszewski A, Garwood J. Bone response to termination of oestrogen treatment. Lancet 1978;i:1325-7.

SIR, - We are surprised by some of the conclusions reached by Dr M R Law and colleagues in their review article on osteoporosis and hip fracture. They state that bone density measurements are not a useful screening test for future hip fracture or for most vertebral fractures. This conclusion seems to be based on the fact that such measurements do not permit discrimination of patients with fractures from controls matched for age and sex. Such discrimination, however, is not necessary because bone density measurements are not intended as a diagnostic test for fractures. ${ }^{2}$ Serum cholesterol measurements do not discriminate between men with and without coronary heart disease, ${ }^{3}$ nor do blood pressure measurements discriminate between those with and without stroke. But bone density, cholesterol, and blood pressure measurements do predict adverse health outcomes. Bone density measurements are clearly related to the incidence of fractures ${ }^{45}$ and are the only way to stratify patients by risk of fracture, thereby permitting intervention before fracture actually occurs

The most successful intervention at present is with the use of hormone replacement therapy. The authors conclude that the protective effect of hormone replacement therapy is lost rapidly when treatment is withdrawn. Two randomised trials that studied the effect of withdrawal of treatment on bone density showed bone loss at a rate comparable with that in untreated women after the menopause. "One study measured bone density in the metacarpal, which is not a site of osteoporotic fracture; the other study measured the distal forearm and showed quite clearly that hormone replacement therapy "bought time" for the skeleton. Thus the age at which fracture risk would be high could be postponed substantially. As yet there are no comparable data for hip measurements.

We are concerned about Dr Law and colleagues' concept of reducing hip fracture by half solely through regular exercise. The largest prospective population study of hip fracture certainly showed that lack of physical activity was associated with an increased risk of fracture." But the confidence intervals of the adjusted odds ratios were large, and it does not seem prudent to estimate the magnitude of the potential reduction that could be achieved through exercise. Furthermore, the increased incidence of hip fracture seen in elderly patients with reduced physical activity may be related to the cause of the reduced physical activity. Those with normal physical activity may be generally healthier, and it does not follow that increasing physical activity will further substantially reduce the incidence of fractures.

We have previously shown that bone density in the hip is significantly higher in postmenopausal women who took regular weight bearing exercise than in those who did not. ${ }^{\times 9}$ However, the difference in bone density between the two groups is only $4 \%$ (SD 0.28 ), while the amount of bone lost between the third and seventh decades is $30 \%$ (2.54). Thus the current self selected exercise pattern of British women seems unlikely to have a major impact on the incidence of hip fractures. Indeed, a greater impact on bone density is seen with increased body weight than with exercise, but that is hardly a reason to recommend obesity as a preventive measure.

Hormone replacement therapy prevents bone loss from the hip ${ }^{10}$ and thus delays an increase in hip fracture risk, but exercise does not prevent or reverse bone loss due to oestrogen deficiency." Patients with increased risk for osteoporosis can be selected by bone density measurements, and hormone replacement therapy may be prescribed to increasing numbers of women for preventing cardiovascular disease in the future. Thus protection against hip fracture will become a beneficia side effect of such treatment. Physical activity should always be encouraged and may effect some reduction in the overall incidence of hip fractures, but it should not be proposed as an alternative to hormone replacement therapy.

JOHN C STEVENSON MICHAEL S MARSH

Wynn Institute for Metabolic Research

London NW8 9SQ 
1 Law MR, Wald NJ, Meade TW. Strategics for prevention of ostcoporid

2 Davis JW, Vogel JM, Ross Pl), Wasnich RD. Disease versus etiology: the distinction should not be lost in the analysis. etrology: the distinction shoul
f Nucl Med 1989:30:1273-6.

3 Melton LJ, Eddy DM, Johnston CC. Inn Intem .Med 1990;112:516-28.

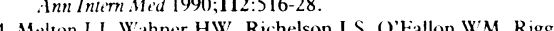
BL. Ostcoporosis and the risk of hip fracture. Am. 7 Epidemio 1986:124:254-61.

5 Hui SJ, Slemenda CW, Johnston CC. Age and bone mass a predicturs of fracture in a prospective study. 7 Clin Inoest
$1988 ; 81: 1804-9$.

6 Lindsay R, Hart DM, Maclean A, Clark AC, Kraszewski A, (iarwood J. Bone response to termination of oestrogen treatment. Luncet 1978;i:1325-7.

7 Christiansen C, Christensen MS, Transhol I. Bone mass in postmenopausal women after withdrawal of oestrogen gestagen replacement therapy. Lancel 1981;i:459-61.

8 Wickham CAC, Walsh K, Cooper C, Barker DJP, Margetts BM, Morris J, et al. Dietary calcium, physical activity, and
risk of hip fracture: a prospective study. BMJ 1989;299:
$889-92$. 889-92.

9 Stevenson JC, Lees B, Devenport M, Cust MP, Ganger KF. Determinants of bone density in normal women: risk factor for future osteoporosis? BMY 1989;298:924-8

(0) Stevenson JC, Cust MP, (iangar KF, Hillard TC, Lees B, Whitehead MI. Oral versus transdermal hormone replacement therapy for prevention of postmenopausal bone loss. Lancet 1990;335:265-9.

11 Lloyd T, Myers C, Buchanan JR, Demers LM. Collegiate women athletes with irregular menses during adolescence
have decreased bone density. Obstet (ivnecol 1988;72:639-42.

SIR, - The recent review on strategies for prevention of osteoporosis and hip fracture by Dr M R Law and colleagues' makes no mention of a role for decreased exposure to sunshine and low body vitamin $\mathrm{D}$ as possible risk factors for hip fracture in the elderly.: Several case-contro studies, ${ }^{3}$ although not all, ${ }^{\times 9}$ have shown that patients with hip fracture have significantly lower blood concentrations of 25-hydroxyvitamin D, a measure of body vitamin $\mathrm{D}$, than do controls. A role for sunlight and vitamin $D$ is supported by the increased incidence of hip fractures during winter when body vitamin $\mathrm{D}$ is low compared with that in summer." Further, vitamin D metabolism may partly explain the inverse association between physical activity and risk of hip fracture as inactive people have lower levels of blood 25-hydroxyvitamin $\mathrm{D}$ than those who are active."

A single oral $2.5 \mathrm{mg}$ dose of vitamin $\mathrm{D}$ (ergocalciferol), at a cost given as $6 \mathrm{p}$ in the 1991 British National Formulary, has been shown to correct vitamin $\mathrm{D}$ deficiency in elderly patients by raising blood concentrations of 25-hydroxyvitamin D for a period of several months without side effects such as hypercalcaemia. ${ }^{12}$ Should future research confirm that vitamin $D$ protects against hip fracture, then vitamin D supplementation of the general population-for example, in winterwould be a cheaper and therefore more practical strategy than using either calcium or postmenopausal oestrogen.

ROBERT SCRAGG

Clinical Gerontology Unit

Addenbrooke's Hospital,

Cambridge CB2 2QQ

1 Law MR, Wald NJ, Meade TW. Strategies for prevention of osteoporosis and hip fracture. BMF 1991;303:453-9. (24 August.

2 Parfit AM, (Gallagher JC, Heaney RP, Johnston CC, Neer R, Whedon (iD). Vitamin $D$ and bone health in the elderly. Am J Clin Nutr 1982;36:1014-31.

3 Pun KK, Wong FHW, Wang C. Vitamin D status amon patients with fractured neck of femur in Hong Kong. Bon 1990;11:365-8.

4 Lau EMC, Woo J, Swaminathan R, MacDonald D, Donnan SPB. Plasma 25-hydroxyvitamin D concentration in patient with hip fracture in Hong Kong. Gerontology 1989;35: with hip

5 Lips $P$, van Ginkel FC, Jongen MJM, Rubertus F, van der Vijgh WJF, Netelenbos JC. Determinants of vitamin D status in patients with hip fracture and in elderly control subjects. in patients with hip fracture and
Am $\mathcal{F}$ Clin Nutr 1987:46:1005-10.

6 Hoikka V, Alhava EM, Savolainen K, Parvainen M. Osteomalacia in fractures of the proximal femur. Acta ()rthop Sian 1982;53:255-60

Baker MR, McDonnell H, Peacock M, Nordin BEC. Plasma 25 hydroxyvitamin $\mathrm{D}$ concentrations in patients with fractures of the femoral neck. BMF 1979;i:589.
8 Lund $\mathrm{B}$, Sorensen $\mathrm{OH}$, Christensen AB. 25-hydroxycholecalciferol and fractures of the proximal femur. Lancet 1975; ii: $300-2$

9 Weisman Y, Salama R, Harell A, Edelstein S. Serum 24,25dihydroxyvitamin $\mathrm{D}$ and 25 -hydroxyvitamin $\mathrm{D}$ concentrations in femoral neck fracture. BMF 1978;ii:1196-7.

10 Jacobsen SJ, Goldberg J, Miles TP, Brody JA, Stiers W, Rimm AA. Seasonal variation in the incidence of hip fracture among AA. Seasonal variation in the incidence of hip fracture among
white persons aged 65 years and older in the United States, white persons aged 65 years and older in the $U$.
1984-1987. Am f Epidemiol 1991;133:996-1004.

11 Scragg R, Holdaway I, Jackson R, Lim ' T. Plasma 25-hydroxy vitamin $D_{2}$ and its relation to physical activity and other hear disease risk factors in the general population. Ann Epidemio (in press).

12 Davies M, Mawer EB, Hann JT, Stephens W/P, Taylor JL.
Vitamin D prophylaxis in the elderly: a simple effective method for large populations. Age Ageing 1985;14:349-54

SIR, - Dr M R Law and colleagues fail to discuss some of the key nutritional influences on calcium balance, and thus possible risk factors for osteoporotic fracture. ${ }^{1}$ The potentially deleterious effects of high intakes of sodium,$^{2}$ protein, ${ }^{3}$ and caffeine ${ }^{4}$ on calcium balance are not mentioned, nor is the possible beneficial effect of trace minerals given together with calcium. ${ }^{5}$ Pharmaceutical preparations of calcium may not be required. Five hundred milligrammes of calcium a day (equivalent to less than three quarters of a pint of semiskimmed milk) may significantly hinder bone loss in women five years or more past the menopause if their calcium intakes are below $400 \mathrm{mg}$ a day.

Menstrual irregularities produced by eating disorders and intensive exercise ${ }^{x}$ may also lower bone density. In addition, the higher fibre intake of vegetarian diets may produce menstrual irregularity, perhaps by the modulation of circulating sex steroids."

Dr Law and colleagues do not discuss factors increasing the tendency to fall. Malnutrition and overmedication in elderly people undoubtedly contribute," especially as subcutaneous fat will cushion the impact of any fall. The antecedents of osteoporotic fracture are numerous and diverse; there is still a need for research.

Rowett Research Institute

ALISON AVENELL

Aberdeen AB2 9SB

1 Law MR, Wald NJ, Meade TW. Strategies for prevention of osteoporosis and hip fracture. BMF 1991;303:453-9. (24 August.

2 Short C, Flynn A. Sodium-calcium inter-relationships with specitic reference to osteoporosis. Nutr Res Rev 1990;3: $101-15$

Kerstetter JE, Allen L.H. Dietary protein increases urinary calcium. F Nutr 1990;120:134-6.

4 Kiel DP, Felson DT, Hannan MT, Anderson JJ, Wilson PW: Caffeine and the risk of hip fracture: the Framingham study. Am f Epidemiol 1990);132:675-84.

5 Saltman P, Strause L. Trace elements in bone metaholism and osteoporosis. F Inorganic Biochem 1991:43:284.

6 Dawson-Hughes B, Dallal GE, Krall EA, Sadowski L, Sahyoun $\mathrm{N}$, Tannenbaum S. A controlled trial of the effect of calcium supplementation on bone density in postmenopausal women. N Engl f Med 1990;323:878-83.

Davies KM, Pearson PH, Huseman CA, Greger NG, Kimmel DK, Recker RR. Reduced bone mineral in patients with eating disorders. Bone 1990;11:143-7.

8 Wolan RL, Clark P, McNally E, Harries M, Reeve J. Menstrual state and exercise as determinants of spinal trabecular bone density in female athletes. $B M \mathcal{F} 1990 ; 301: 516-8$.

9 Pedersen AB, Bartholomew MJ, Dolence LA, Aljadir LP, Netteburg KL, Lloyd T. Menstrual differences due to vegetarian and nonvegetarian diets. Am f Clin Nutr 1991;53: $879-85$.

10 Vellas B, Conceicao J, Lafont C, Fontan B, Garry PJ, Adoue D, et al. Malnutrition and falls. Lancet 1990;336: 1447 .

SIR, - In Dr M R Law and colleagues' cogent review of strategies for the prevention of osteoporosis and thereby hip fracture' we were surprised to see no mention of the importance of reducing sodium intake. This omission was particularly surprising in view of their recent series of papers on the importance of sodium intake in high blood pressure. ${ }^{2-}$

For many years it has been known that sodium intake is one of the major determinants of urinary calcium excretion ${ }^{5}$ and in quantitative terms that this is more important than the calcium intake." For instance, over the range of sodium intake in Western communities, calcium excretion would vary from approximately $3.5 \mathrm{mmol} /$ day on a $50 \mathrm{mmol}$ sodium intake to approximately $5.0 \mathrm{mmol} /$ day on a sodium intake of $200 \mathrm{mmol} / \mathrm{day}$, assuming a calcium intake of approximately $800 \mathrm{mg} /$ day. A high salt intake is associated with increased levels of parathyroid hormone, an increase in hydroxyproline excretion (a marker of bone resorption), and a rise in serum osteocalcin concentration (a marker of bone formation). ' In menopausal women, many of whom will have a net negative calcium balance of about $1 \mathrm{mmol} /$ day, this will cause an annual bone loss of $1 \cdot 5 \%$, amounting to $15 \%$ in a decade. ${ }^{8} \mathrm{~A}$ reduction in salt intake from the average in the United Kingdom of $170 \mathrm{mmol} /$ day to $70 \mathrm{mmol} /$ day, as recently recommended by the Department of Health, ${ }^{9}$ would reduce urinary calcium excretion by an average of $0.6 \mathrm{mmol} / \mathrm{day}$. This is likely to slow down the progression of bone demineralisation and clinical osteoporosis. At the very least this reduction in sodium intake would substitute the need for an increase in calcium intake which, as Dr Law and colleagues rightly point out, is an extremely expensive way of trying to prevent osteoporosis and carries potential risks.

Thiazide diuretics given to men and women with or without hypertension reduced the number of hip fractures. ${ }^{11}$ The mechanism whereby thiazides cause a reduction in urinary calcium excretion and a positive calcium balance is similar to that occurring when sodium intake is lowered. An advantage of a reduction in sodium intake is that it does not have the metabolic side effects of the diuretic. Although we would agree with Dr Law and colleagues that increased exercise, smoking cessation, and oestrogen replacement are useful strategies, we would feel that salt intake should be reduced as this in itself could slow down or even prevent the development of osteoporosis. A reduction in salt intake is likely to be more feasible both on an individual basis and as a population strategy, particularly if the food industry is prepared to cooperate. A reduction in salt intake has the advantage of lowering blood pressure and reducing cardiovascular risk. ${ }^{4}$

FRANCESCO P CAPPUCCIO GRAHAM A MACGREGOR

Blood Pressure Unit,

Department of Medicine,

St George's Hospital Medical School,

London SW' 17 ORE

1 Law MR, Wald JN, Meade TW Strategies for prevention of osteoporosis and hip fracture. BMF 1991;303:453-9. (24 August.

2 Law MR, Frost CD, Wald NJ. By how much does dietary salt reduction lower blood pressure? I. Analysis of observational data among populations. BMJ 1991;302:811-5. (6 April.)

3 Frost CD, Law MR, Wald NJ. II. Analysis of observational data within population. $B M \mathcal{F} 1991 ; 302: 815-8$. (6 April.)

+ Law MR, Frost CD, Wald NJ. III. Analysis of data from trial of salt reduction. BMJ 1991;302:819-24. (6 April.)

5 McCarron DA, Rankin LI, Bennett WM, et al. Urinary calcium excretion at extremes of sodium intake in normal man. A $m$ J Nephrol 1981;1:84-90.

6 Cappuccio FP, Markandu ND, Beynon (GW, Shore AC, MacGregor GA. Effect of increasing calcium intake on urinary sodium excretion in normotensive subjects. Clin $S_{C}$ 1986;71:453-6.

7 McParland BE, Goulding A, Camphell AJ. Dietary salt affects hiochemical markers of resorption and formation of bone in bichemical markers of resorption and

8 Goulding A, Everitt HE, Cooney JM, Spears GFS. Sodium and osteoporosis. In: Wahlqvist ML, Truswell AS, eds. Recent adrances in clinical nutrition. London: John Libbey, 1986: advances

9 Department of Health. Dietary reference values for food energy and nutrients for the United Kingdom. London: HMSO, 1991 Report on health and social subjects 41 .

10 Wesnick R, Davis J, Ross P, Vogel J. Effect of thiazide on rates of bone mineral loss: a longitudinal study. BMF 1990;301 $1303-5$

11 LeCroix AZ, Wienpahi J, White LR, et al. Thiazide diuretic agents and the incidence of hip fracture. $N$ Engl $7 \mathrm{Med}$ 1990;322:286-90

SIR, - In their review of strategies for preventing osteoporosis and hip fracture Dr M R Law and colleagues claimed that bone densitometry had little role in screening for osteoporosis or even in its 